\title{
RESEARCH OF ACOUSTIC EMISSION SIGNALS AT DESTRUCTION OF GRAPHITE
}

\author{
V. Babak, S. Filonenko, V. Kalita
}

National Aviation University, Kiev, Ukraine.E-mail:fils@ukrpost.net

Received 2209 2005, accepted 06032006

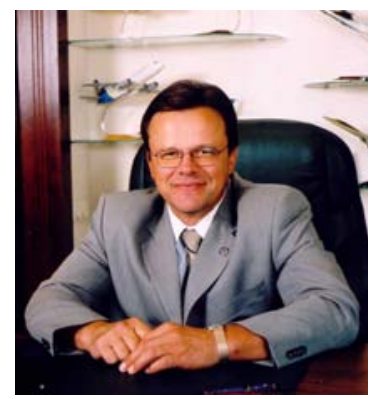

Vitaly BABAK, Prof Dr Habil

A Corresponded member of the National academy of science of Ukraine, the doctor of engineering science, professor, a honored figure of science and engineering of Ukraine, a winner of the State award of Ukraine in the area of science and technique.

Date and place of birth: 1954, Lubny, Ukraine

Education: Kiev Polytechnic Institute, 1977. 1995 - PhD from Kiev Polytechnic Institute.

Affiliations and functions: 1977-1995 - an assistant, an assistant professor, a professor, the head of faculty of Kiev Polytechnic Institute. 1995-1998 - the deputy minister of education of Ukraine. Science 1998 - the President of the National Aviation University, Kiev, Ukraine

Research interests: diagnostics of technological processes, signal processing.

Publications: over 330 scientific papers, including 45 monographs, textbooks, dictionaries, 36 patents.

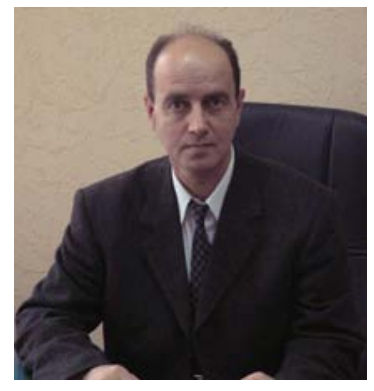

Sergay FILONENKO, Prof Dr Habil

Date and place of birth: 1954, Echmiadzin, Armenia.

Education: Kiev Polytechnic Institute.

Affiliations and functions: deputy director Institute of Information-Diagnostic Systems at National Aviation University since 2000, 2003 - PhD from National Aviation University.

Research interests: diagnostics of technological processes, automatic diagnostic systems.

Publications: over 130 books and articles.

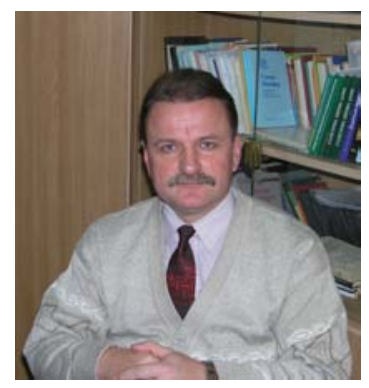

Viktor KALITA, Cand. of Sci.

Date and place of birth: 1962, Chernigov, Ukraine.

Education: Rostov on Don State University.

Affiliations and functions: Assistant Professor of physics, National Aviation University since 2000, 1991 -

Cand. of Sci. (Eng.) from Rostov on Don State University.

Research interests: solid-state physics, technical diagnostics

Publications: over 46 articles.

Abstract. The results of experimental research of acoustic emission signals at destruction of different diameter graphite cylindrical models are considered. It is stated that dependence of area under the curve of acoustic emission signals is directly proportional to the area of an appearing crack.

Keywords: acoustic emission, strength, cracks growth, loading, acoustic emission signal, strength distribution, fracture, structural heterogeneity, graphite.

\section{Introduction}

The use of the phenomenon of acoustic emission (AE) in technical diagnostics of different units suggests the accomplishing of studies that are directed to the establishment of interconnection between parameters of the registered signals and the parameters of processes taking place in material structure under action of different fac- 
tors. The research of AE appearing at plastic deformation and destruction of materials has a particular interest. It is caused by the fact that these processes have the decisive influence on bearing strength of units.

There are many works related to the research of acoustic emission regularities at static and dynamic loading of materials. At the same time, the results received frequently do not correlate with each other and even have a contradictory character. This concerns both theoretical and experimental results of studies. For example, the modeling of AE signals allows not only the extension of the overview of the phenomenon of AE but also the determination of directions of research of information parameters for the check. Such modeling of signals at the formation of cracks in material, carried out with the use of different approaches (dislocation models of crack formation, formation of fragile crack at the direct atomic decoupling, calculation of alteration in the fields of strain and dislocations at formation of cracks of the normal tearing off and transversal shear, show that primary AE signal is a videopulse $[21,20,11,25,4,7]$. Research results show, however, that the parameters of AE signals, received at different approaches in the creation of models, differ among themselves. The duration of fore wavefront (signal) of AE coincides with the time crack opening and for a crack of normal tearing off makes a size of $\tau_{1}=2 \ell / c_{1}$, where $2 \ell$ is the length of a crack and $c_{1}$ is the velocity of longitudinal waves [22]. The duration of fore front $\tau_{1}$ and its steepness $S_{B}$ is defined through velocity of the crack expansion $v_{T}$ and time of its bound $\tau_{1}=t_{c}$, the duration of the fore front being equal to time of bound, and the steepness has a more complex expression $\mathrm{S}_{\mathrm{B}}=2 \sigma v_{\mathrm{T}} /\left(\rho \mathrm{c}_{1}^{2}\right)$, where $\sigma$ is cleavage stress of destruction [8]. Duration of the forefront is bound to the area of destruction: $t_{m}=a \sqrt{S}$ where $a$ is the constant, the numeral value of which for different materials lies between $(1.5-2.5), \mathrm{S}$ - the square of destruction (the appearing crack) [2].

Unlike theoretical research data, analysis of the experimental results based on the registration of $\mathrm{AE}$ is frequently conducted by exploring amplitudes of AE signals, because it is determined that at the approach to the critical stage of destruction there is an increase in the number of high amplitude AE signals. At the subcritical growth of a crack, when increment of a crack is insignificant and much less that the length of the crack itself, it is supposed that the absence of the imposition of AE signals, the number of correlations describing interconnection of increase in length of crack with amplitude of AE signals is defined. This connection is represented in the following way: $\sum_{i} \Delta \ell_{i} \sim \sum_{i} U_{i}^{2}$, where $\Delta \ell_{i}$ is size of $i$-st step of crack propagation and $U_{i}$ is the amplitude of $i$-st $A E$ signal [9]. Such a connection is represented in another way: $\sum_{i} \Delta \ell_{i} \sim \sum_{i}\left(U_{i}\right)^{2}$ [5]. For this correlation a fractional degree is received: $\sum_{i} \Delta \ell_{i} \sim \sum_{i}\left(U_{i}^{\prime}\right)^{2 / 3}$, where in- tegral amplitude of a signal is used for the time span of crack growth $U_{i}^{\prime}=\int_{0}^{\Delta t_{i}} U_{i}(t) d t$ [11]. Other possible correlations relating to the amplitude $\mathrm{AE}$ signals with the parameters of the crack growth have been also analyzed, for example, with its area $[23,6]$.

There are fewer works related to research of $\mathrm{AE}$ at plastic deformation of materials than there are about crack formation. At plastic deformation, as a rule, dependence of the modification of the quantity of AE signals is analyzed. In this case, in the theoretical and experimental correlations, the dependence between the modification of quantity of AE signals and the coefficient of strain intensity $K_{\mathrm{I}}$ is investigated $[11,8,10]$. In this case, based on the supposition that if material possesses sufficient plasticity, and the modification of volume of plastic area is the main source of AE signals, the number of signals must be proportional to the number of elementary sources in the plastic deformed volume, i.e., where $V_{p}$ is the plastic deformed volume of material, the size of which is defined by the coefficient of strain intensity of $K_{\mathrm{I}}$ [3]. The works do not give an analysis of the parameters of individual AE signals. One of the reasons for the lack of experimental research of parameters of AE signals at plastic deformation is the absence of any models that are suitable to experimental verification and of clear criteria for the selection of the signals.

A theoretical description of AE signals was made both at formation and propagation of the crack in material and flowage $[13,15,14]$. In these works, unlike those quoted above, the modeling of AE signals at crack formation is based on the supposition that destruction of material takes place in the area of heterogeneity, when local strains get the tensile strength. Destruction of every local area of material is accompanied by elementary pulses, which in aggregate form the AE signal. It is principally important that such a model supposes the possibility of the account of the influence of kinetics of process of destruction on the acoustic radiation, including the process of the self-acceleration crack growth. During plastic deformation, the AE signal is examined as a result of imposition of the pulses radiated by any dislocation that moves independently. At the modeling of AE signals, in accordance with the developed models, the good correlation of their form with the form of the real AE signals is received $[13,15,14,12]$. The calculations of AE signal parameters, allowed intercommunication between the parameters of signals and parameters of an appearing crack to be defined [16]. This intercommunication is not set experimentally, however.

Thus, the problem of establishing the interconnection between the AE signal parameters and the processes that take place in material appears extraordinarily actual. It can be fixed only during detailed experiments connected with the use of more sophisticated methods of recording and processing the AE signal, methods that give the opportunity to analyze both forms of signals and determine their parameters. Thus, in such research, the character of $\mathrm{AE}$ radiation and its parameters must be properly correlated with the properties of the defect that 
appears, the determination of which is one of main difficulties of the experiments conducted.

In this work, the results of experimental research of AE signals are presented at the formation of a fragile crack at destruction of graphite models with different dimensions. The data from the processing of AE signals, received with the use of a mobile AE system that allows temporal associations of the modification of the primary and secondary parameters of the registered signals to be received, can be analyzed and processed according to parameters and forms. The results of processing the AE signal demonstrated a selfacceleration character of the crack propagation, very complicated kinetics of destruction process, accompanied with the local braking and acceleration of developing process. It will be showed that the area under the curve of the AE signals is directly proportional to the area of the crack that appears, which has good correlation with the model of presentation of destruction process $[13,15,14]$.

\section{Test method}

The processes of material loading, as is generally known, are accompanied by the development of microand macro deformations in their structure, by the formation of submicro- and microcracks, which are characterized by the different volume of the material that is involved in the process and the different area of the cracks that appear [17]. Reproducing of the indicated values repetition during material tests can be regarded as a complication task. Therefore for obtaining reliable dependencies of modification of AE signals parameters from the parameters of developing defects, and, above all, parameters of appearing cracks, it is necessary to have model materials. Graphite belongs to the class of materials, the structure of which allows the above-mentioned conditions to be satisfied.

The structure of graphite is a continuous row of layers parallel to the basic plane and consisting of carbon hexagonal atoms related to each other, and the distance between any neighboring atoms of carbon in the enplane base layer is less than the distance between atoms in neighboring layers. The link between atoms within the limits of a layer is metallic and more intensive than it is between atoms from different layers, which have Van der Waals type links. This results in the anisotropy of physical properties of graphite in the directions that are parallel and perpendicular to the layers. At molding of graphite we get polycrystal models with the arbitrary orientation of polycrystal axes, though there is some anisotropy of its properties, related to the direction of molding. At the identical condition of loading of equivalent models it is possible to expect the reproduction of cracks of approximately identical size. Due to this, graphite has found a use as an imitator of AE signals during the calibration of AE equipment $[2,27]$.

For this research 20 standard bars made of graphite of identical hardness of $\mathrm{HB}$ and diameters of $0.3 \mathrm{~mm}, 0.5$ $\mathrm{mm}, 0.7 \mathrm{~mm}, 0.9 \mathrm{~mm}$, and $2 \mathrm{~mm}$ were used. During the tests, bars were set in opening drilled in a plastic plate at an angle of $30^{\circ}$ and at a depth of $5 \mathrm{~mm}$ (Fig 1). Their loading was carried out with a permanent velocity equal to $1 \mathrm{~mm} / \mathrm{min}$, in the direction perpendicular to the axis of the bar.

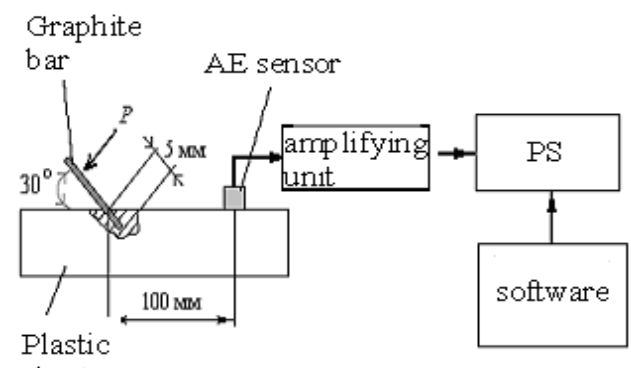

sheet

Fig 1. Method of testing graphite bars

At a distance of $100 \mathrm{~mm}$ from the pinhole on the plate, an AE sensor was set in a layer of acoustictransparent lubricant (Fig 1). Electric signals from the output of the sensor were increased by an amplifying unit, transformed into a digital code, and recorded by a personal computer. Further signal processing was carried out with the use of software (MS). The AE sensor was a broadband sensor with a bandwidth equal to the bandwidth of the amplifying unit, $100 \mathrm{\kappa Hz}-2000 \mathrm{\kappa Hz}$. The sensitivity of the amplifying unit was $7 \mu \mathrm{kV}$ and the amplification coefficient was 20000 . The software used was an independent integrated environment in which all processes of handling measurements, processing the recorded information, and presenting its results are performed as modification of AE signals parameters in time [1]. Thus the measuring system carries out the storage of initial AE signals, determination of criteria estimations with the purpose of selection of signals from cracks, and the calculation of parameters of every individual signal: amplitude, power, energy, duration, etc.

\section{Results obtained}

Tests of graphite models have shown that their loading is accompanied by the radiation of AE signals, which appear at the moment of destruction of graphite (Fig 2). Thus signals do not appear before destruction.

Figure 2 shows that the average amplitude of $\mathrm{AE}$ signals is a result of time scale, which considerably exceeds time of destruction process. Such presentation of results shows the presence of single splash that is identical for all tested models. We can note that in many works devoted to the research of $\mathrm{AE}$, the results of measuring are represented as average associations of modification of parameters of AE signals, similar to the splash that are presented in Figure 2. Such an approach, however, does not allow an analysis of the parameters of the individual signals recorded during the tests of models and caused by processes that take place in their structure to be conducted.

The tests conducted show that at the destruction of the graphite bars, a few AE signals (3-5 signals) follow in sequence in small intervals of time, are fixed. Thus the first of these signals has maximal energy that by twothree orders exceeds the energy of the other AE signals. 
The Energy of this first signal amounts to more than $99 \%$ of general recorded energy. Presumably, the second and following signals registered are related to imperfections of the method of testing (friction, impacting of blasted parts, etc). Therefore, the analysis was later conducted only for the first AE signal.

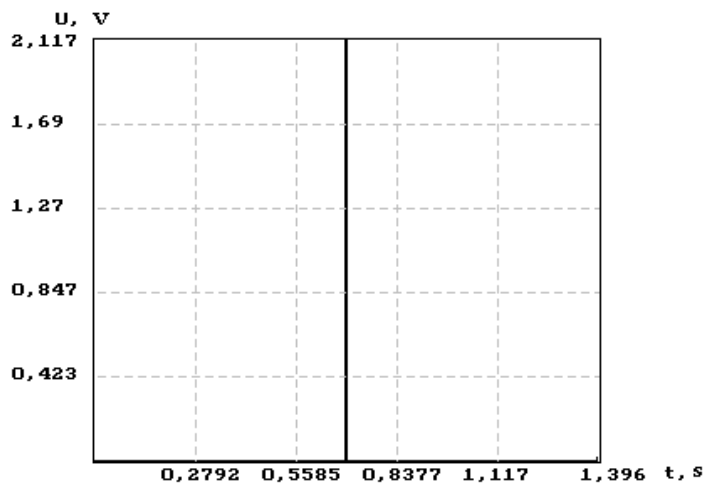

Fig 2. Dependence of modification of the average amplitude of AE signals during testing of graphite bar with a diameter 0.3 $\mathrm{mm}$. Average time is $0.1 \mathrm{~ms}$

It should be noted that the first signal processing with the use of criterion of $K_{\mathrm{p}}$ confirms, that this AE signal is a signal from a crack $[27,26]$.

Figure 3 presents the characteristic AE signals received during the test of graphite models of different diameters. It is clear from Figure 3 that the recorded AE signals have a rather complicated form. At the fore and back fronts of signals, there is a modification of their steep nesses and non-regularities of amplitude. However, the value of amplitude non-regularities at the fronts of signals changes with the modification of the diameter of the bars. For the bar with the smallest diameter,

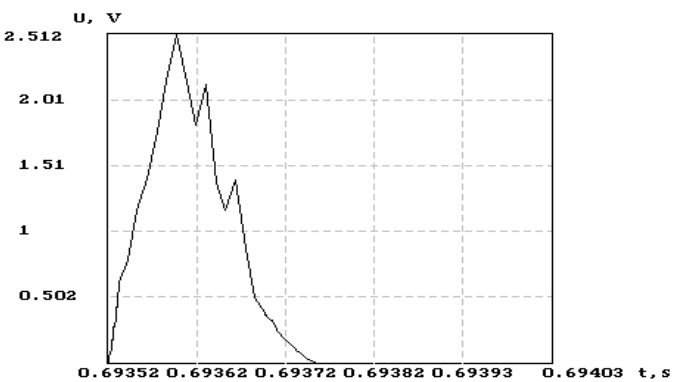

a)

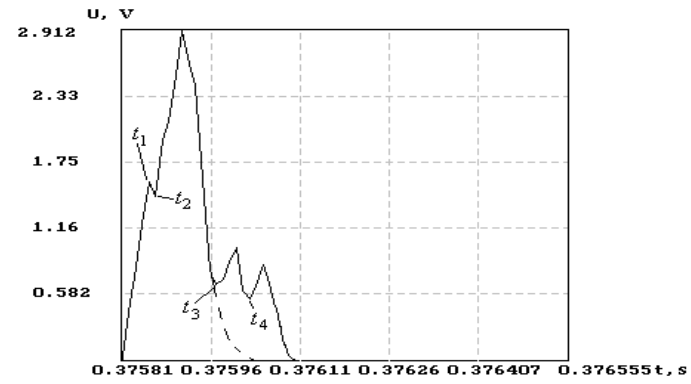

b)

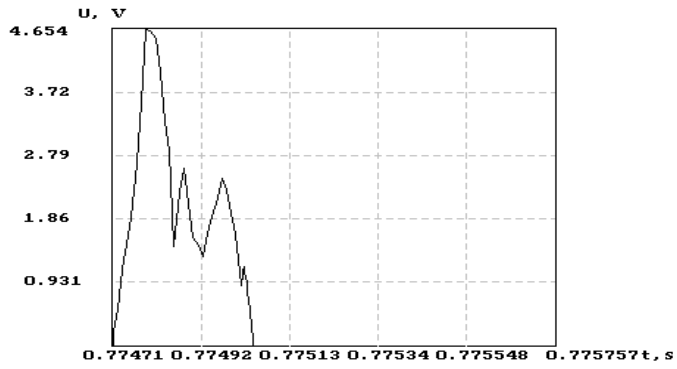

c)

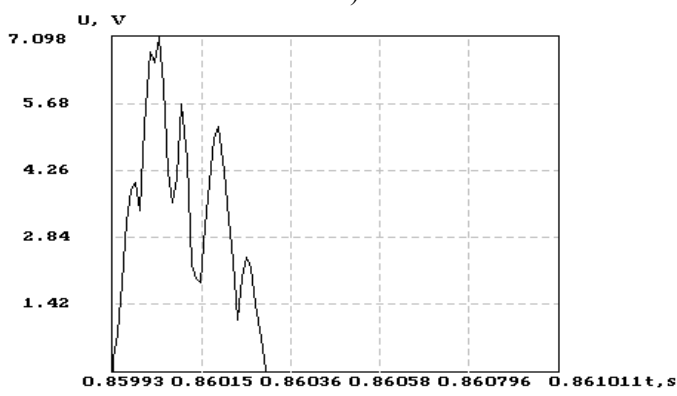

d)

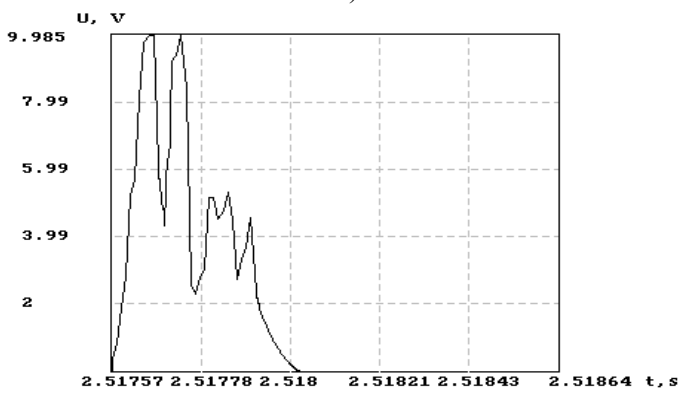

e)

Fig 3. AE signals forms recorded at destruction of graphite bars in accordance with the method presented in Fig.1, $a$. Diameter of bars: $a-0.3 \mathrm{\text {м } ;} b-0.5 \mathrm{\text {м}} ; c-0.7 \mathrm{\text {мм}} d-0.9 \mathrm{\text {м}} ; e-2$ $\mathrm{mm} . t_{1}, t_{2}$ are moments of time of modification of velocity of crack growth in the initial stage of its propagation; $t_{3}, t_{4}-$ moments of time of the non-regular growth of crack

These non-regularities of amplitude are insignificant. With the increase in diameter, these non-regularities increase, so that for the greatest diameter there is the impression that the recorded signal appears as the sum of a few poorly blocked signals.

The complicated form of the recorded AE signals, cut up by the non-regularities of amplitude, is evidence that crack propagation in the models tested is characterized by an uneven (unstable) appearance, which is presumably caused by the modification of the velocity of their appearance and growth. In accordance with the character of the modification of the AE signals, the noted modifications of velocity in the appearance and growth of cracks exist, both on initial (fore front of signal) and eventual stages (back front of signal) of its development. It follows from the data received that the instability of crack growth showing up in the non-regularities of amplitude changes with the increase in diameter of the graphite models tested. For the small diameter the cut up of $\mathrm{AE}$ signal is not considerable (Fig 3,a). That is related to the almost continuous crack propagation [12]. With the in- 
crease in the diameter of models, the cut up of signals increases (Fig 3). That is, probably related to the propagation of a crack-taking place in stages or surges in large diameter models. Thus, at first there is the formation of an initial crack of a certain size, and in the future it develops by stages, eventually leading to the complete destruction of the model.

\section{Analysis of AE signals}

As mentioned above, the cut up of AE signals indicate the change of kinetics of crack propagation or related to the change a velocity of crack propagation. Because it was not possible to track the process of crack formation and growth (with fixing of geometrical sizes and instantaneous position), we carried out a search for parameters related to the recorded signals with the geometrical parameters of the tested graphite bars. According to the accepted method of tests, models were destroyed transversal to the axis of a bar. This is why it is natural to analyze the alteration in the parameters of AE signals depending on the square of the cross section of the bars.

For example, Figure 4 show the graph of relation of duration of AE signals which is resulted from the area of bars cross-section: $\tau=f_{1}\left(\mathrm{~S}_{\mathrm{T}}\right)$. The values of AE signals duration are marked by areas, corresponding to the average values received for every group of bars of identical diameter. In fig. 4 it is visible that with the increase in the area of the bars, the duration of signals increases. However, this growth takes place slower than the growth in the area of the cross-section of the bars, and, consequently, the area of the crack that appears. The approximation of the data presented in Fig. 4, shows that they are described by the expression $\tau=k S_{T}^{n}$. Thus, the index of degree $n$ is equals $=0.46$. It is therefore possible to consider within the limits of error that $\tau=k \sqrt{S_{T}}$, where $k$ is the coefficient of proportion, i.e. the duration of signals is proportional to the diameter (or radius) of a bar. Such a correlation between the duration of the AE signal and diameter of a bar can be explained as the process of distraction is developing with a constant speed. However, complicated forms of signals do not to allow this supposition to be accepted (Fig 3).

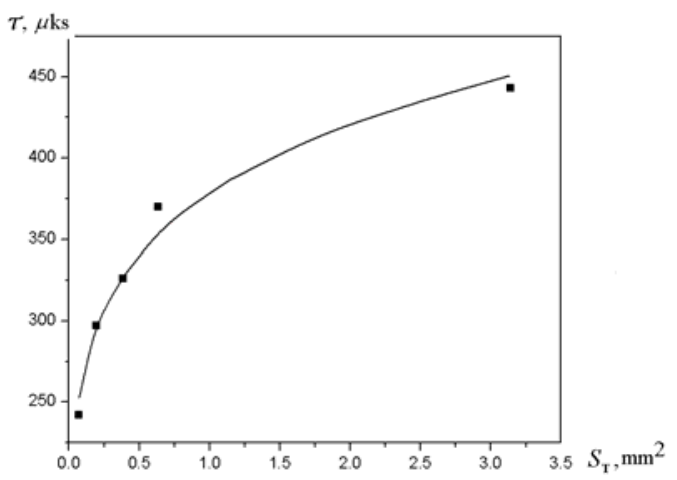

Fig 4. The dependence of the modification of the average amplitude of AE signals on the area of the cross-section of the graphite models
Figure 5 presents the dependence of the alteration of maximal amplitude of the AE signals registered on the area of bars: $U_{\max }=f_{2}\left(\mathrm{~S}_{\mathrm{T}}\right)$. The value of amplitudes of $\mathrm{AE}$ signals shown on the graph, and marked by areas, corresponds to the mean values received for every group of bars of identical diameter. It is visible in Figure 5 that with the increase of the area of the bars, the amplitude of AE signals increases similarly. However, a large part of this growth takes place more slowly than the growth in the area of the cross-section of the bars. Approximation of the data presented in Figure 5, has shown that they are also defined by the relation of a power function with the index of power $n=0.44$. Actually, according to the approximation, it is possible to consider that the maximal amplitude is proportional to the diameter of the bars. The received proportionality of AE signal maximum amplitude to diameter of bars does not correspond with known information and is difficult to explain. Quite obviously, that the value of $\mathrm{AE}$ amplitude must depend on failure strain, i.e. it does not depend on the diameter of the samples.

The amplitude of the signal depends not only on the area of destruction but also on the velocity of its development $[13,12]$. The last, referring to Figure 3, has a complicated forms. However, it is necessary to take into account that the product of duration and maximum value of the amplitude is approximately proportional to the square root of the area under the AE signal. Taking into account that the duration and maximum of amplitudes of signals are proportional to the

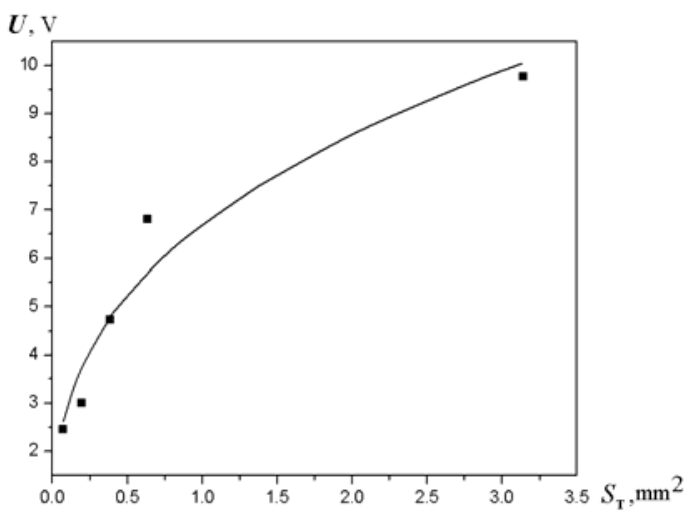

Fig 5. The dependence of alteration of the average amplitude of $\mathrm{AE}$ signals on the area of the cross-section of graphite models

square root of the area of the cross-section of the bars, it is necessary to expect that the area under the AE signals must be proportional to the area of the cross-section of the bars. For verification of this supposition from data of the AE signal processing the graph of the relation of the area under signals from the area of the cross-section of the bars was created: $S_{\mathrm{c}}=f_{3}\left(\mathrm{~S}_{\mathrm{T}}\right)$, which is presented on Figure 6.

The square under signals is averaged during all measuring for every series of the tested models of identical diameter. Values of the area under the curve of AE for bars of identical diameter on the graph are presented as 
rectangles, the altitude of which shows the variation of values of $S_{\mathrm{c}}$.

In Figure 6, it can be seen that the relation between the area under the curve of the AE signals and the area of the cross-section of the bars has a linear character of growth. The received results are described by the function:

$$
S_{c}=0.0951+1.1592 S_{T},
$$

where $S_{\mathrm{c}}$ and $S_{\mathrm{T}}$ are the area under the curve of the AE signal and the area of the cross-section of the model. The minimum dispersion was the criterion of approximation of the experimental data, the value of which for (1) is equal to $\sigma^{2}=0.0809$.

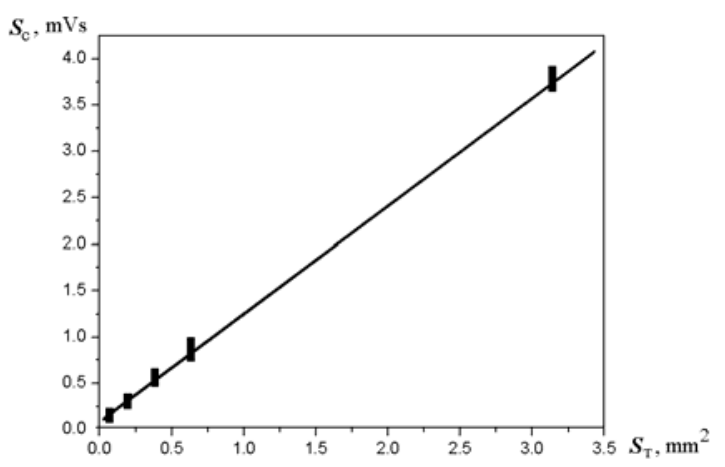

Fig 6. Dependence of the area under the curve of AE signals $\left(S_{\mathrm{c}}\right)$ on the area of the cross-section of graphite bars $\left(S_{\mathrm{T}}\right)$ during shearing test

The given relation corresponds to the results of the theoretical research presented in [16] work, where it was shown that during appearance and growth of the crack, the parameter that does not depend on the velocity of its propagation is presented by the area under the AE signal curve. Thus its value must be directly proportional to the area of the crack. All the other parameters of the AE signal are defined by kinetics of process of material, which takes place in its structure. According to Figure 3, the kinetics of these processes develops with complications with the presence of stages of slower and faster growth of the crack. At the same time, the curve that is presented in Figure 4 specifies that growth in the destruction time take place more slowly than the growth of the area of the crack. It can be shown that the destruction process, on the average, has got an accelerated character, which corresponds to kinetic theory of strength [24].

\section{Conclusion}

The results of this research show that at the destruction of graphite bars, there is a good repeatability in the registered AE signals for the models of the same diameter. The analysis of signals allows to their modification to be described depending on the diameter of the tested models. It has been shown that the fragility of signals increases with the growth of diameter that specifies complicated character of the developing process of destruction with its braking and acceleration. Processing the parameters of $\mathrm{AE}$ signals demonstrated that the area under the AE signals is directly proportional to the area of the cross-section of the model. This result correlates well with the results of theoretical research. At the same time, the duration and maximal amplitude of the AE signals are defined by the kinetics of the destruction process, and regularities in their alteration testify the presence of acceleration (on the average) in its development.

\section{References}

1. Babak V.P., Filonenko S.F. Mobile informationalmeasuring system for technical diagnostic of items // International conference: Sensors \& Systems. Proceedings.- Saint-Petersburg, 2002. -Vol II P.143-147.

2. Dunegan H.L. An alternative to pencil leads breaks for simulation of acoustic emission signal sources // The DECI REPORT. - 2000 August. - 5 p.

3. Dunegan H.L., Harris D.O., Tatro C.A. Fracture analysis by use of acoustic emission // Eng. Fract.Mechanics. - 1968. - Vol I, No 1 - P.105-122.

4. Eda H., Kanino Y. et al. In process detection of grinding cracks by use of acoustic emission // Bull. Japan Sc. Of Pre. Eng. - 1985. - Vol IX, No 3. P.181-186.

5. Green A.T. Detection of incipient failures in pressure vessels by stress wave emission // Nuclear safety. - 1969. -Vol X, No 1. - P.4-18.

6. Gerberich W.W., Alteridge D.G., Lessar J.F. Acoustic emission investigation of microscopic ductile fructure // Met.Transf. - 1975. - Vol VI A, No2. - P.797-801.

7. Hamstadt M.A., O'Gallagher A., Gary J. Modeling of buried acoustic emission monopole and dipole sources with a finite element technique // Journal of acoustic emission. - 1999. - Vol XVII, No 3-4. - P. 97-110.

8. Hartbower C.E., Reuter W.G., Morais C.F. Acoustic emission for the detection of weld stresscorrosion cracking // Acoustic emission. ASTM, STP 505. - Baltimore, 1972. - P.187-221.

9. Landy R.J., Ono K. Acoustic emission behavior of a low alloy steel // Journal of Acoust. Emiss. -1982. - No 1. - P. 7-19.

10. Palmer I.G., Heald P.T. The application of acoustic emission to fracture mechanics // Mater. Science and Enginering. - 1973. - Vol XI. - P.181-184.

11. Андрейкин А.Е., Лысак Н.В. Метод акустической эмиссии в исследовании процессов разрушения. - К: Наукова думка, 1989. - 176 с.

12. Бабак В.П., Філоненко С.Ф., Калита В.М. Моделювання сигналів акустичної емісії при виникненні в матеріалі тріщин // Вісник НАУ.2002. -№ 1. - С. 5-10.

13. Бабак В.П., Филоненко С.Ф., Калита В.М. Модели формирования сигналов акустической эмиссии при деформировании и разрушении материалов // Технологические системы. - 2002. - №1(12). - C. 26-34. 
14. Бабак В.П., Филоненко С.Ф., Калита В.М. Моделирование сигналов акустической эмиссии при протекании в материале пластической деформации // Технологические системы. - 2002. - №3(14). - С.77-81.

15. Бабак В.П., Филоненко С.Ф., Калита В.М. Модель сигнала акустической эмиссии при образовании в материале трещины с учетом релаксационных процессов // Технологические системы. - 2002. - № 5(16). -С. 20-23.

16. Бабак В.П., Филоненко С.Ф., Калита В.М. Оценки информативности параметров сигналов акустической эмиссии // Технологические системы. - 2003. - № 3(19). - С.65-69.

17. Бернштейн М.Л., Займовский В.А. Структура и механические свойства металлов. - M: Металлургия, 1970. - 472 с.

18. Болотин Ю.И., Маслов В.А., Полунин В.И. Установление корреляции между размером трещины и амплитудой импульсов акустической эмиссии // Дефектоскопия. - 1975. -№ 4. - С. 119-122.

19. Грешников В.А., Дробот Ю.В. Акустическая эмиссия. Применение акустической эмиссии для испытаний материалов и изделий. - М.: Изд-во стандартов, 1976. -272 с.

20. Иванов В.И. Акустическая эмиссия в процессе когерентного разрушения // Доклады АН СССР. 1986. Т. 287, № 2. - С.302-306.

21. Иванов В.И., Белов В.М. Акусто-эмиссионный контроль сварки и сварных соединений. - М: Машиностроение, 1981. -184 с.
22. Маслов Л.А., Щигрин Б.Н. Общие принципы действия трещины, как излучателя упругих волн и связь еe параметров с характеристиками сигналов акустической эмиссии // Дефектоскопия. - 1977. - № 1.- С. 103-112.

23. Несмашный Е.В., Кузнецов В.А., Маслов Б.А. и др. О связи амплитуды сигналов акустической эмиссии с приращением площади трещины // I-я Bсес. конф.: Акустическая эмиссия материалов и конструкций (Ростов-на-Дону, 11-13 сентября 1984) Сб. тез. докл. - Ростов-на-Дону: Сев. Кавк. научн. центр высш. школы, 1985. - Ч 1. - С.224225.

24. Регель В.Р., Слуцкер А.И., Томашевский Э.Е. Кинетическая природа прочности твердых тел. М.:Наука, 1974. - 560 с.

25. Станчиц С.А., Томилин Н.Г. Исследование временных параметров акустических сигналов при образовании трещин отрыва // Прогноз землетрясений. - 1983. - № 4. - С.31-45.

26. Филоненко С.Ф. Акустическая эмиссия. Измерение, контроль, диагностика. - К.:Издат-во КМУГА, 1999. -304 с.

27. Филоненко С.Ф. Анализ достоверности критериальной оценки выделения сигналов акустический эмиссии от трещин на источнике Су Нильсона // Автоматика, автоматизация, электротехнические комплексы и системы. 2001. -№2. - C. 33-39. 